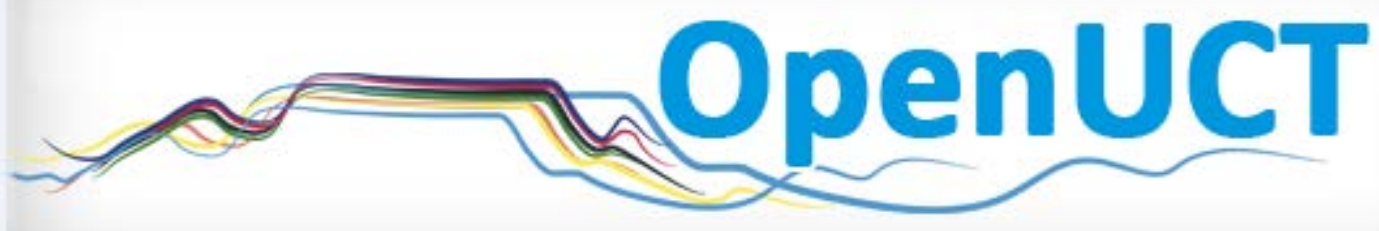

This is the post-print of Jawitz, J. 2009. Learning in the academic workplace: the harmonization of the collective and the individual habitus. Studies in Higher Education. 34(6): 601-614. DOI: 10.1080/03075070802556149.

It is made available according to the terms of agreement between the author and the journal, and in accordance with UCT's open access policy available:

http://www.openuct.uct.ac.za/sites/default/files/UCTOpenAccessPolicy.pdf, for the purposes of research, teaching and private study. 


\title{
Learning in the academic workplace: the harmonization of the collective and the individual habitus
}

\author{
Jeff Jawitz*
}

\begin{abstract}
One of the challenges of research into social practice is finding a way to take both the structural aspects of the social contexts and individual agency into account. This paper describes the use of Bourdieu's social practice theory together with Lave and Wenger's situated learning theory to understand how the learning of practice takes place within the academic workplace. Drawing on interviews with academics across three departments at a research intensive historically white university in South Africa, I explored how new academics engaged with the assessment practices in their departments and developed their confidence to judge student performance of complex assessment tasks. The study provides a set of conceptual tools for academic staff development practitioners to use in supporting academics in their learning to teach. An argument is made for the process of learning in the workplace to be understood in terms of the harmonization of the individual habitus with the collective habitus in the departmental communities of practice.

Evidence is also provided of the importance of context in understanding how academics learn.
\end{abstract}

\section{Learning in the academic workplace}

Theories of social practice regard learning as arising out of the social relationships within the workplace or learning environment (Billett 2001; Brown, Collins and Duguid 1989; Eraut 2004; Lave 1996; Lave and Wenger 1991). In this perspective learning results from participating 'in the practices of social communities and constructing identities in relation to these communities' (Wenger 1998, 4). It is viewed as the 'inevitable product of everyday thinking and acting, shaped by workplace practices in which individuals participate' (Billett 2001, 19). The structure of work activities and the nature of relationships in the workplace provide opportunities for learning. The majority of these opportunities consist of informal learning experiences involving 'learning from other people and learning from personal experience' (Eraut 2004, 248). Billett (2004) argues that in many workplaces structured pathways of activities exist for newcomers that are 'inherently pedagogical' and provide 'access to the knowledge needed to sustain those practices’ (Billett 2004, 119).

At one level these theories appear to foreground the structural aspects of the experience of learning for newcomers to a social context. Some authors have highlighted the difficulties experienced by new academics entering a department in exerting their agency as they engage with the 'understandings and assumptions held collectively in the community of practice' (Trowler and Knight 2000, 31). For example, assessment practice in higher education involves tacit knowledge that often cannot be described because 'the assessor's knowledge exists in the practice of the skill and not in a set of published maxims' (Gonzalez Arnal and Burwood 2003, 383). Learning to assess complex student performance involves 'participating in relevant social practices, observing, copying [and] imitating' (Gonzalez Arnal and Burwood 2003, 386).

This article reports on a study into how academics learn to judge student performance in complex assessment tasks in three departments at the South African University (SAU) a historically white research intensive university. The names of the institution and departments involved have been changed to protect their identities. The study drew on Bourdieu's theory of practice to analyse the relationship between individual academics and the structuring potential of their academic contexts,

\footnotetext{
${ }^{*}$ Correspondence: HAESDU, Centre for Higher Education Development, University of Cape Town,
} 
and Lave and Wenger's situated learning theory to explore how academics learn through participation in a community of practice.

The concepts of field, capital and habitus are central to Bourdieu's theory of practice.

A field consists of a set of objective, historical relations between positions anchored in certain forms of power (or capital) . . . a relational configuration ... which it imposes on all the objects and agents which enter in it. (Bourdieu and Wacquant 1992, 16-17)

A close study of the three departments highlighted the dynamic nature of the field of higher education at SAU. The pressures for change form part of a social revolution in South Africa demanding transformation and greater social responsiveness and accountability from the higher education sector. Pressures also arise from the growth of new disciplines and interdisciplinary research challenging older configurations of academic life and organisation. Each of the three case studies revealed academic practices that were evolving in the midst of ongoing change including: increasing student numbers; changing employment requirements for new academics; changing age, race or gender profiles of academic staff; the merging of departments and emergence of new sub-disciplines, and changing models of departmental leadership.

The field of higher education itself contains several fields, such as those associated with the disciplines or professions, in which particular forms of capital are valued. Bourdieu identifies four forms of capital: economic, social, cultural and symbolic capital (Bourdieu and Wacquant 1992). Economic capital refers to access to economic resources and is usually related to income and wealth. Social capital is based on the network of social relations that individuals establish and build; cultural capital is accumulated through the process of education, and symbolic capital is derived from 'culturally significant attributes such as prestige, status and authority’ (Mahar, Harker and Wilkes 1990, 13).

Within social practice theory, each individual in a field carries a habitus which is 'all at once a "craft", a collection of techniques, references, a set of "beliefs" ' (Bourdieu 1993, 72-3) formed out of past experiences and socialisation processes. However the concept of habitus encapsulates more than just experience. Each individual's habitus also generates strategies that form the basis of the actions they perform in the field. Bourdieu argues that these actions can be 'consistent with the objective interests of their authors without having been expressly designed to that end' (Bourdieu 1993, 76). Furthermore, the habitus of individuals exposed to the same fields and the same 'logic of action' over an extended period of time, gives rise to a 'class habitus' which 'enables practices to be objectively harmonized without any . . . direct intervention or . . explicit co-ordination’ (Bourdieu 1990, 58).

How new academics experience the effects of the field they enter is shaped by the capital that they bring. The acquisition of the tacit knowledge of academic practice favours newcomers with forms of cultural capital that match the capital valued by the field. As newcomers become aware of the limitations of their capital within their new contexts, their habitus generates strategies to 'maximize their capital' and ensure their continued participation in the field. But the field imposes limits on what strategies and actions a newcomer may successfully adopt without resistance. In particular the older members of the field tend to resist changes to the field that could threaten their monopoly of the capital (Bourdieu 1993).

The central focus of situated learning theory is the relationship between individual agents and communities through engagement with practice. According to situated learning theory knowledge is distributed amongst the members of a community of practice and can only be understood with the 'interpretive support' provided by participation in the community of practice itself (Lave and Wenger 1991). A community of practice is constituted by the way people interact with each other and thereby establish and 'tune' their 'relations with each other' through mutual engagement in a joint enterprise, using a shared repertoire of 'routines, words, tools, ways of doing things' (Wenger 1998, 83).

Legitimate peripheral participation forms the basis of learning and progress towards more advanced participation within the community of practice (Lave and Wenger 1991). It involves the newcomer being exposed to what the community of practice values through initial engagement with legitimate 
tasks, in a peripheral capacity, and with low levels of responsibility. As the experience of participation increases so the newcomer's identity settles into one or other trajectory linking past experiences with future possibilities of membership of the community of practice (Wenger 1998). Wenger suggests that certain 'paradigmatic trajectories' have greater significance than others as they 'embody the history of the community' and that 'exposure to this field of paradigmatic trajectories is likely to be the most influential factor shaping the learning of newcomers' (Wenger 1998, 156). But as this study reveals newcomers have agency and might choose a trajectory other than the paradigmatic one.

\section{The study}

Between 2004 and 2006, 31 academics were interviewed across three departments chosen to represent significantly different disciplinary contexts in the academic workplace. Department B in the Faculty of Natural Science was chosen as a department where research was dominant, while Department C in the Faculty of Design was chosen because of the importance of professional work in departmental life and the limited role of research with only $10 \%$ of academics having completed a doctoral degree. All three departments had recently appointed academics, had members keen to participate in the study, and had strong national and international reputations. As such they represented a set of best cases (Flyvbjerg 2001). For Department A in the Faculty of Social Science, with over 20 academics and large undergraduate classes, a purposive sampling for race and gender was used. In the two smaller departments all academics were approached. One declined and three others were unavailable at the time of the study.

The case study method allows the 'case narrative to unfold from the diverse, complex and sometimes conflicting stories that people, documents and other evidence tell', leaving room for the reader to participate in the process of interpretation (Flyvbjerg 2001, 86). This approach strengthens the 'credibility' and facilitates the 'transferability' of the research (Lincoln and Guba 1985). Polkinghorne (1995) identifies two kinds of inquiry into narratives. In the one, 'analysis of narratives', data is collected in the form of stories, often interviews, and analysed to identify common themes and concepts. In the other, 'narrative analysis', the researcher collects 'descriptions of events and happenings' and 'synthesizes' them into a story 'that provides an explanatory answer to the questions' (Polkinghorne 1995, 15). The analysis of data involved iteration between these two forms of inquiry until it was possible to formulate an answer to the research question of how academics learn to judge student performance in complex assessment tasks.

The focus on the marking of complex assessment tasks was chosen as these require substantial judgement on the part of an academic. Complex assessment tasks involve students in responding to questions or activities that are open ended and require them to use their initiative. As such student responses can take a range of forms that it is often not possible to predict in advance.

\section{The findings}

At one level, an answer to the research question appeared frequently in the interview data in the form of two discourse models (Gee 1996) namely, that academics 'learn by doing' and that 'help is available - all one has to do is ask'. These discourse models form part of a habitus that spans across all three departments and serves to misrecognise (Bourdieu 1990) how learning occurs by disguising the distributed nature of the knowledge of practice, and reinforcing the view that the responsibility for learning lies with the individual.

Analysis of the case studies revealed distinct clusters of activity around the key functions of teaching, research and professional practice. The act of participating in these activities formed the bases of distinct communities of practice. These CoPs functioned within fields, but also behaved as fields, valuing particular forms of cultural capital, i.e. research, teaching or professional capital. Each case 
study revealed a distinct relational configuration of communities of practice and significantly different entry requirements and career trajectories into academia (Figure 1).

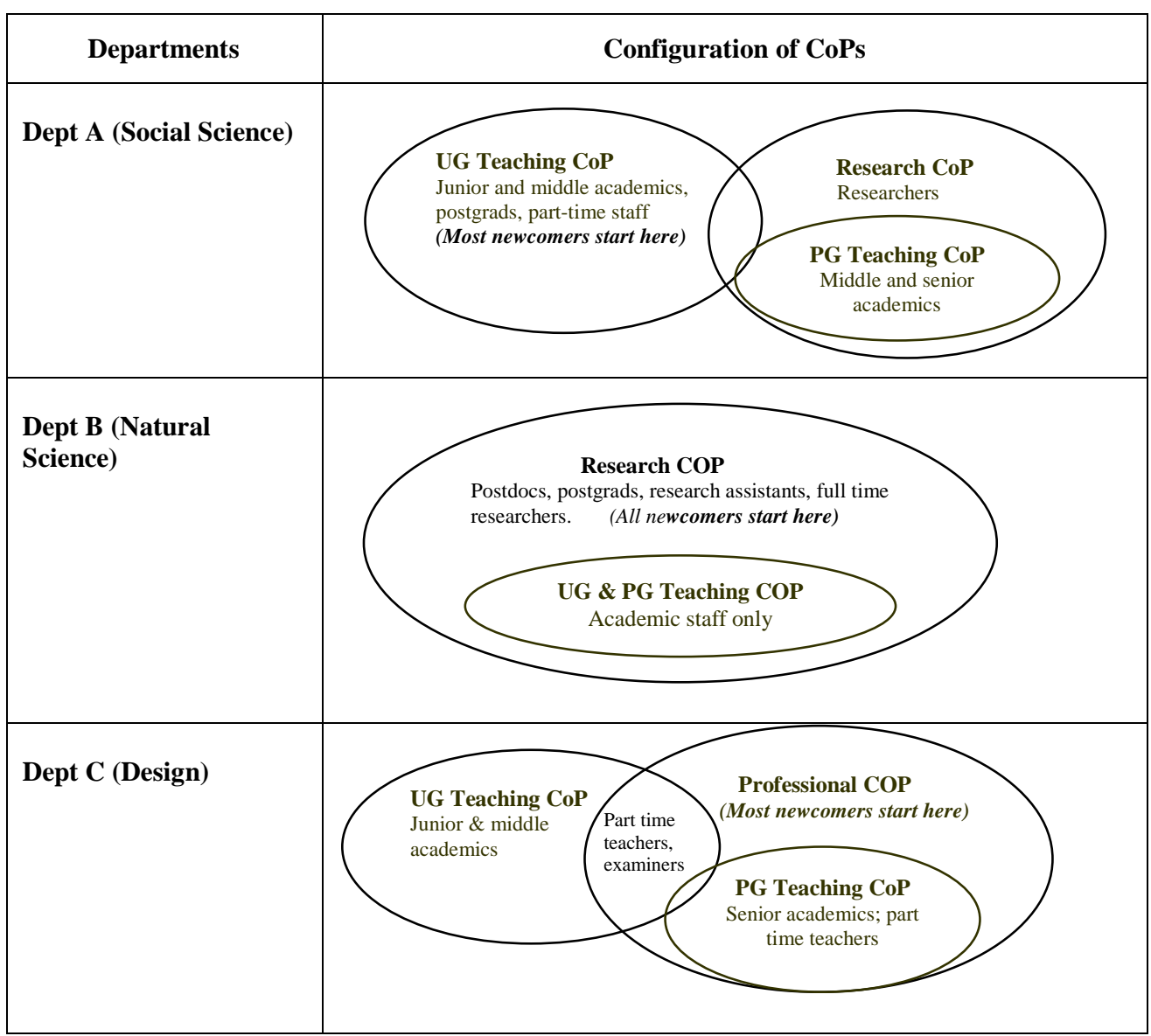

Figure 1: The configurations of communities of practice in the three departments

A careful analysis of the data facilitated a mapping of the opportunities to mark key complex assessment tasks onto the typical career trajectory in each case study. This revealed a set of structured pathways (Billet, 2004) that I have chosen to refer to as learning-to-judge trajectories (Figures 3, 4 and 6). These trajectories illustrate how the notion of 'learning by doing' can arise out of an engagement over time with a 'learning curriculum' (Lave and Wenger 1991) that forms part of the field within which an academic department is situated. Within each case study the configuration of communities of practice and the learning-to-judge trajectory impacted significantly on how newcomers learned to judge student performance.

Upon arrival in the academic workplace, a newcomer enters a field with a particular configuration of communities of practice. The typical career trajectory involves participation in a specific sequence of assessment tasks along the learning-to-judge trajectory. In trying to understand the process of learning in this context, I define two new concepts. The first is the collective habitus of a community of practice, akin to Bourdieu's 'class habitus' but operating at the local rather than at the level of social classes. Within the collective habitus resides the 'shared repertoire of . . . ways of doing things' (Wenger 1998). The second concept is that of habitus harmonization which describes the process whereby the habitus of a newcomer and the collective habitus of a community of practice adjust to each other. This harmonization process, arising out of the interaction between the agency of new academics and these key contextual aspects within the workplace, forms the basis of learning in the 
academic workplace. In the remainder of this paper an explanation of how learning to judge student performance occurred within each of the case studies is presented.

\section{Learning in Department A (Social Science)}

In Department A (Social Science) the experience of new academics was fundamentally shaped by their interaction with the two largely separate communities of practice (Figure 1), the undergraduate (UG) teaching $\mathrm{CoP}$ and the research $\mathrm{CoP}$, with a postgraduate (PG) teaching CoP embedded within the latter (Jawitz 2007). Large numbers of postgraduate students served as tutors and part time lecturers for the large classes on the periphery of the undergraduate teaching CoP. Most of the full time academics at the time of this study were themselves graduates of the department and had served in this way while completing their Masters degrees prior to appointment.

All new academics were assigned to teach within the undergraduate teaching $\mathrm{CoP}$ and movement into the research CoP depended on demonstrating progress in research. The absence of older, more experienced academic staff from the undergraduate teaching $\mathrm{CoP}$ meant that new academics were left to find their own way into the practice of teaching and assessment in the department.

The old school have actually stopped teaching [undergraduates]. Teaching is now concentrated amongst the middle group but in particular the junior staff. . . . I mean that's standard practice. You start in the varsity, they throw you all the junior . . . teaching load. . . . As your research output grows .... the less and less teaching you are required to do. . . . That's the kind of progression. [Julius 68]

While the majority of academics interviewed followed the typical career trajectories, and began their academic lives in the positions indicated in Figure 1a, not everyone did. The stories told by Julius and Henrietta highlight how the development of the academic habitus of individuals within the same context can be differently constructed.

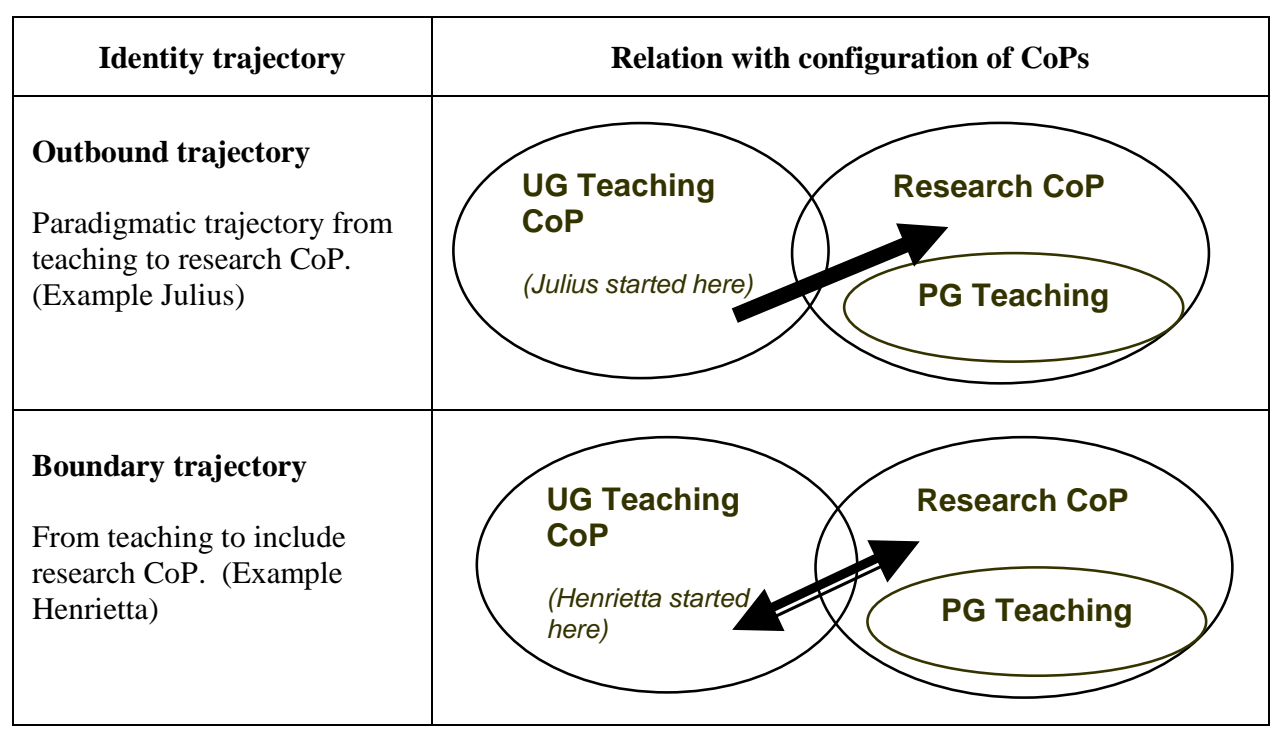

Figure 2: Identity trajectories in Department A (Social Science)

Both Julius and Henrietta initially focused their energies on becoming full members of the undergraduate teaching $\mathrm{CoP}$ and developed reputations as innovative and committed teachers. For Julius, progress as an academic meant moving out of the undergraduate teaching CoP into the research $\mathrm{CoP}$ as promotion depended largely on research (Figure 2). In contrast, Henrietta, while expressing a commitment to research wished to engage with 'transforming what we do here' in teaching. She defined herself as a change agent and was actively engaged in challenging the assessment and teaching practice in the department. Participation in the undergraduate teaching CoP formed an integral part of her academic identity, her habitus, and she constructed a boundary trajectory that sought to include 
full membership of both communities of practice (Figure 2). Because her research and her teaching activities were 'so far apart' she had strategised to offer to teach a course that 'nobody else wants'. This had empowered her to negotiate that all her teaching happened in one semester and enabled her to sustain membership of both communities of practice.

From their first year of appointment, new academics in this department participated annually in two key complex assessment tasks, the marking of undergraduate essays and research papers for the postgraduate Honours Degree (Honours research papers). While there was no formal support for new academics in these tasks the learning-to-judge trajectory in the department was relatively well structured (Figure 3). It began with the process of marking essays as a postgraduate tutor, on the periphery of the undergraduate teaching CoP, and extended over several years across a range of increasingly complex assessment tasks to the marking of Masters theses as a full member of the research CoP. Support activities organized by course convenors for postgraduate tutors in their marking of undergraduate essays offered significant opportunities for LPP. As such they provided a safe environment for potential academics to learn how to judge student performance with limited responsibility and no risk to their reputations as academics. Cindy felt that she 'got a lot more learning how to mark' while working as a tutor than since her appointment as a full time lecturer. She indicated that 'the lecturer ... spent a significant amount of time with us going through essays ... as to what's a good essay, what's a bad essay.'

The process of managing these tutors in their marking involved newly appointed academics in monitoring and moderating the marking of essays through regular discussions between themselves, tutors and other lecturers. Their experience of the conversations that formed part of this activity was a significant part of their own learning-to-judge trajectory.

\begin{tabular}{|c|c|c|}
\hline \multicolumn{3}{|l|}{ Career Trajectory } \\
\hline $\begin{array}{l}\text { Post grad tutor - on } \\
\text { periphery of undergraduate } \\
\text { teaching CoP }\end{array}$ & $\begin{array}{l}\text { Academic - in } \\
\text { undergraduate teaching } \\
\text { CoP }\end{array}$ & $\begin{array}{l}\text { Academic - in research } \mathrm{CoP} \\
\text { and postgraduate teaching } \\
\text { CoP }\end{array}$ \\
\hline $\begin{array}{l}\text { a) Mark undergraduate essays } \\
\text { under supervision. (LPP }\end{array}$ & $\begin{array}{l}\text { b) Mark und raduate } \\
\text { essays }\end{array}$ & f) Mark postgraduate essays \\
\hline & $\begin{array}{l}\text { c) Manage tutors marking } \\
\text { essays }\end{array}$ & \\
\hline & & e) Mark Masters thesis \\
\hline
\end{tabular}

Figure 3: The learning-to-judge trajectory in Department A (Social Science)

However in the marking of the Honours research paper there was no peripherality. Each paper was marked by the student supervisor and one other academic who each submitted a report justifying their mark. If the marks differed by less than $10 \%$ the average was taken. If the marks differed by more than $10 \%$ the course convenor negotiated a compromise between the two markers. These negotiations often highlighted the power relations between senior and junior academics. The fear of having to defend one's mark against that of an experienced colleague had a significant impact on how new academics marked. The dominant experience of new academics was of having to work out a mark alone and of adopting 'detection avoidance' strategies to protect their reputations as academics by assigning marks in their judgement of student performance that did not draw attention to themselves.

You don't want to highlight your incompetence by failing everyone, that being reviewed, and finding out what an appalling marker you end up being. So it's this kind of detection avoidance scheme. . . . In the beginning . . . you err on the side of generosity . . . because that way it's less controversial . . . less chance of being hauled up to substantiate your decisions. [Alan 102] 
The tutor management system, the double marking of Honours research papers, the markers written reports and the feedback from the external examiner, can collectively be viewed as a set of mechanisms which, together with the experience en route the learning-to-judge trajectory, was central in helping to 'harmonize' the newcomers' academic habitus with that of the collective habitus in relation to judging student performance. These mechanisms helped to ensure that new academics developed a 'feel for the game' (Bourdieu 1993) and were able to produce judgements that supported the departmental system of assessment and did not put their academic reputation at risk.

\section{Learning in Department B (Natural Science)}

In Department B (Natural Science) all new academics joined the research CoP on arrival in the department having completed a doctoral degree and having accumulated substantial research experience as a postdoctoral researcher. All academics taught at both undergraduate and postgraduate levels within a single teaching $\mathrm{CoP}$. The department's undergraduate programme did not teach first year students. They offered courses at second year level in the specializations in Natural Science associated with the department's areas of research. The aim of the undergraduate programme was to prepare students to do research. As a result of this high degree of synergy between teaching and research in the department, the teaching $\mathrm{CoP}$ can be represented as being embedded within the research CoP (Figure 1). No postgraduate students or part time lecturers were involved in teaching. A key incentive for all academic staff to teach at the undergraduate level appeared to be the need to attract students into one's sub-discipline and to secure postgraduate students for oneself at Honours, Masters and Doctoral degree levels. In this context the 'paradigmatic' career trajectory, starting from the research $\mathrm{CoP}$ and incorporating working in the teaching $\mathrm{CoP}$, appeared to be the only identity trajectory available for academics in the department.

The ability to judge what constituted a 'good' paper was strongly aligned with the ability to judge 'good' research. As new academics were appointed with the necessary research capital it was assumed that the making of such judgements would be unproblematic. The view of assessment as an 'objective' search for the 'right mark' was pervasive within the department strongly influenced by the rationality of scientific research. Judging student performance was regarded as an individual and private activity to be conducted independently and in an 'unbiased' way. Discussion of student work between markers was discouraged and significant differences in the double marking of Honours research papers were resolved administratively, by appointing an additional marker and by taking the arithmetic average to determine the final mark, often without the knowledge of the markers concerned. As a result there was no significant conversation or feedback to markers about the judgement process.

\begin{tabular}{|c|c|c|c|}
\hline \multicolumn{4}{|c|}{ Career Trajectory } \\
\hline \multirow{9}{*}{$\begin{array}{l}\text { Postgraduate } \\
\text { student on } \\
\text { periphery of } \\
\text { research CoP } \\
\end{array}$} & Postdoc in & Academic - in research & teaching CoP \\
\hline & & $1^{\text {st }}$ Semester & $2^{\text {nd }}$ semester \\
\hline & & $\begin{array}{l}\text { Mark Honours specialist } \\
\text { essay }\end{array}$ & \\
\hline & & $\begin{array}{l}\text { Mark Honours propolal } \\
\text { presentation }\end{array}$ & \\
\hline & & $\begin{array}{l}\text { Mark Honours literat re } \\
\text { review }\end{array}$ & \\
\hline & & & Mark $3^{\text {rd }}$ yr project \\
\hline & & 1 & Mark Honours paper \\
\hline & & $\downarrow$ & $\begin{array}{l}\text { Mark Honours } \\
\text { presentation }\end{array}$ \\
\hline & & & $\begin{array}{l}\text { Mark Masters } \\
\text { Thesis }\end{array}$ \\
\hline
\end{tabular}

Figure 4: The learning-to-judge trajectory in Department B (Natural Science) 
In this department all newcomers were required to judge student performance in several complex assessment tasks in quick succession in their very first year of appointment (Figure 4). While the repetition of this cycle each year providing the opportunity to learn from the previous years' experience, given the lack of feedback or discussion about assessment, each academic was left to reflect on their own experience and there was no opportunity for legitimate peripheral participation.

Jane, a new lecturer, commented that 'I'm marking true to myself but I don't know whether I'm marking true to how the department marks.' She found that her marks ended up being 'very similar' to that of the second marker and commented that even though one may be looking for different things 'it all evens out in the end'. This notion of the inevitable convergence of marks, despite the use of different assessment criteria, emerged several times in the data and formed part of the collective habitus.

The initial discomfort evident amongst new academics with the lack of agreed criteria for assessing student performance, eventually gave way to an acceptance that individuals could mark in any way they pleased and that mechanisms were in place to ensure an appropriate mark would be awarded to the student. Learning to judge in this context involved adopting an individualistic approach, knowing that there were mechanisms for arriving at a final mark irrespective of what mark you gave. Newcomers soon stopped searching for a collective set of rules and criteria for marking. The individual habitus became harmonized with a collective habitus that held that it was possible to arrive at an 'objective' judgement on one's own without discussion. The development of confidence could be said to have been based on a realization that there was no need to reach agreement, as structures were in place to ensure a mark would be awarded anyway, a habitus coming to terms with the uncoordinated harmonization of practices (Bourdieu 1990).

\section{Learning in Department C (Design)}

In Department C (Design) most academics began their careers working as professionals who taught part-time or examined in the department and later applied for fulltime appointment. As new academics they were assigned to teach in the undergraduate CoP. There was a separation of the sites of participation of junior and senior academics as the more senior academics only taught postgraduate courses and engaged in their private professional practice as part of a broader professional CoP (Figure 1). The use of large numbers of professional practitioners as part-time lecturers and examiners, authentic assessment tasks linked to professional practice throughout the curriculum, and the time devoted by senior academics to sustaining their professional practice, were evidence of the high value of professional capital within the department.

It's a department which is academically driven by ... people who have a practitioners' identity rather than a purely academic one ... There's a lack of research culture . . . and it affects the induction of staff, because the role models are people ... who succeed as practitioners rather than as academics. [Frank 51]

As in Department A (Social Science) the agency of individuals in interaction with the field resulted in a range of identity trajectories (Figure 5). The paradigmatic identity trajectory represented by senior academics, Stuart and Roger, was an outbound trajectory from the undergraduate teaching CoP into the professional CoP. Frank, Zaid and Majdi, had joined the department after experience in professional practice. Zaid and Majdi were trying to sustain a boundary trajectory between the professional and undergraduate teaching CoPs. In contrast, Frank had recently completed a postgraduate course in teaching, had taken over as convenor of the undergraduate education programme, and had begun to disengage himself from professional practice. He was constructing an identity trajectory out of the professional CoP into the undergraduate teaching CoP. 


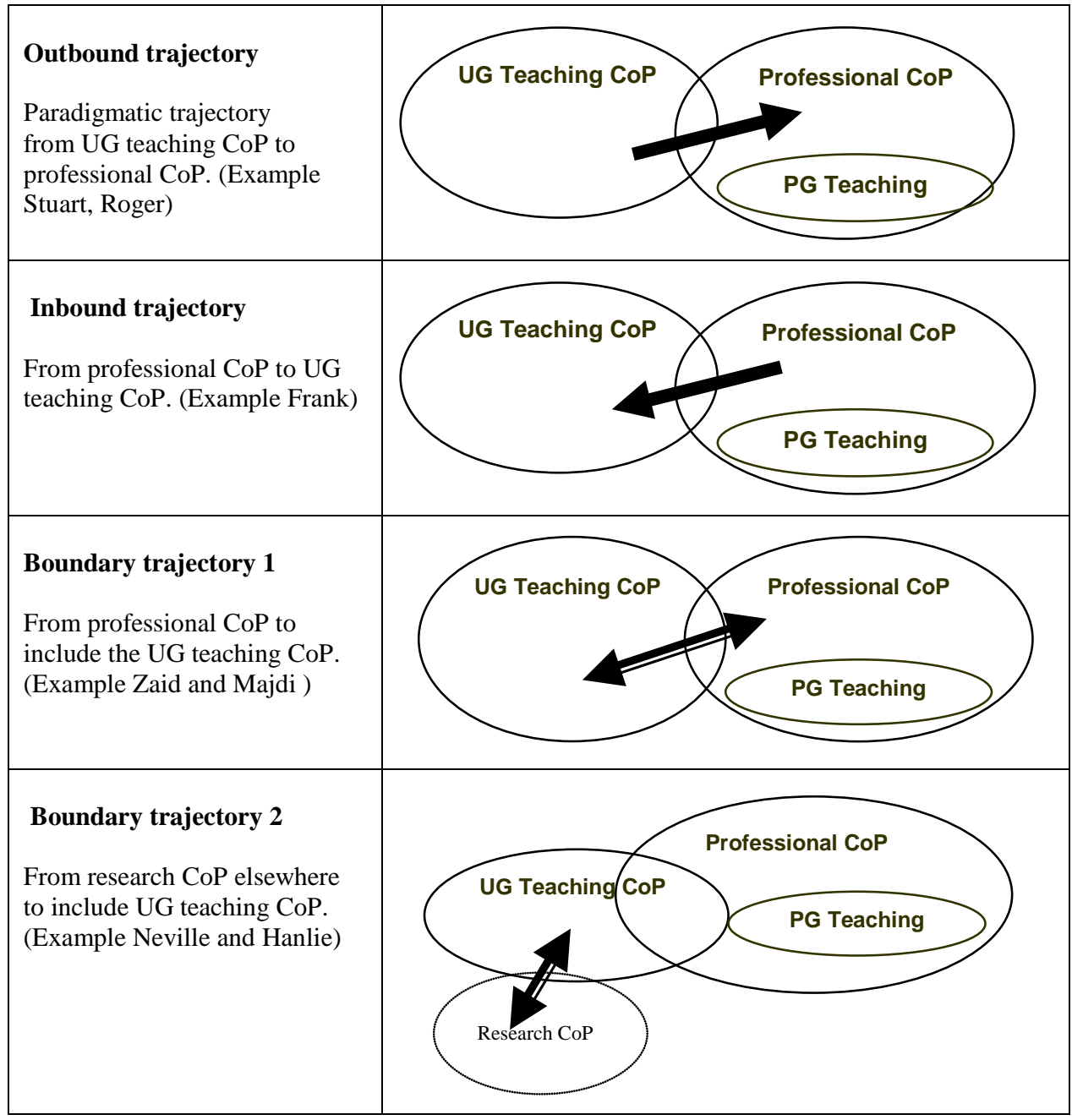

Figure 5: Identity trajectories in Department C (Design)

As in Department A (Social Science) the learning to judge trajectory for design was spread out over an extended period of time (Figure 6). Multiple opportunities to participate in peer and self assessment activities in the undergraduate curriculum provided substantial legitimate peripheral participation experiences for academics in judging performance during their years as students. The dominance of the verbal mode of assessment and the public nature of the assessment process were unique features of this context. They provided new academics and students with regular access to the discourse of judging performance and opportunities to observe and listen until they felt ready to contribute.

[As] a student you're having to . . . understand the way in which you're working, be able to communicate that ... to defend that and you're always in discussion with other people about that, your peers and your teachers. ... You see other people going through that . . . it's very visible. [Frank 101-105] 


\begin{tabular}{|c|c|c|c|}
\hline \multicolumn{4}{|c|}{ Career Trajectory } \\
\hline $\begin{array}{l}\text { Student }- \text { on } \\
\text { periphery of } \\
\text { UG teaching } \\
\text { CoP }\end{array}$ & $\begin{array}{l}\text { Professional - on } \\
\text { periphery of UG } \\
\text { teaching CoP } \\
\text { \& in professional CoP }\end{array}$ & $\begin{array}{l}\text { Academic - in UG } \\
\text { teaching CoP }\end{array}$ & $\begin{array}{l}\text { Academic - in PG } \\
\text { teaching CoP \& in } \\
\text { Professional CoP }\end{array}$ \\
\hline \multirow{3}{*}{$\begin{array}{l}\text { Mark design as } \\
\text { student; self and } \\
\text { peer assessment. } \\
\text { (LPP } \\
\text { experience) }\end{array}$} & $\begin{array}{l}\text { Mark design as Part } \\
\text { time design teacher/ext } \\
\text { examiner }\end{array}$ & $\begin{array}{l}\text { Mark design at undergrad } \\
\text { level }\end{array}$ & $\begin{array}{l}\text { Mark design at post } \\
\text { grad level }\end{array}$ \\
\hline & (LPP possible) & (LPP possible) & \\
\hline & & $\begin{array}{l}\text { Mark undergrad theory } \\
\text { essay }\end{array}$ & $\begin{array}{l}\text { Mark post grad theory } \\
\text { essay }\end{array}$ \\
\hline
\end{tabular}

Figure 6: The learning to judge trajectory in Department C (Design)

Key:

Learning to judge trajectory for design

Learning to judge trajectory for theory essays

The widespread use of teams of markers, including part time professionals and new academics, and the substantial discussions that occurred within these teams, offered several opportunities for legitimate peripheral participation in relation to assessment and provided newcomers with some degree of peripherality. Watching a mark being put forward and argued for until consensus was reached formed a significant part of the process of harmonization of the individual habitus with the collective habitus. While newcomers were vulnerable to the power relations in the department in this process, with time they were able to work out how to make judgements in line with those of their colleagues.

What makes it easier here is that it's a consensus mark and it has to be argued. . . People have to motivate why they think a mark should be a certain mark or what is wrong or what is right about a project ... then it becomes quite clear. [Pat 186]

Zaid, a new black academic in the department, had experienced the collective habitus of his white colleagues in the undergraduate teaching community of practice as having a racial bias. His resistance to being 'harmonized' into their practice of judging black students more leniently than white students highlights some of the complexities of learning to judge student performance at a South African university. He initiated a discussion of this practice with his colleagues and began the process of renegotiating the notion of racism in relation to assessment within the teaching community of practice. He was supported in this process both by a black external examiner who shared his concerns and the willingness of his colleagues to acknowledge the problematic nature of this aspect of their practice. Here is an instance where the agency of a newcomer might lead to the collective habitus having to adapt to the individual habitus of the newcomer.

Learning to judge theory essays in Department C (Design) was a very individual process. Experience of this process only began after appointment as an academic and appeared to be closely aligned with the development of research expertise. However within this department the courses within which these theory essays were set were regarded as marginal and resulted in only limited individual research based activity. Some new academics found support in this learning by being assigned to co-teach theory courses with a colleague.

\section{Conclusion}


This study highlights the importance of context in understanding learning in the academic workplace. While an examination of context may reveal structured pathways for learning such as the learning-tojudge trajectories, these pathways alone may not provide the necessary support for all newcomers. The significant variation in configurations of communities of practice, the way social and disciplinary factors shape assessment practice and the kinds of judgements newcomers are required to make, and the alignment of key complex assessment tasks with particular forms of capital, are important considerations in understanding the ease, or difficulty, with which new academics learn to judge student performance.

While in Departments A (Social Science) and C (Design) there were several opportunities for newcomers to map out their own particular identity trajectories, in Department B (Natural Science) the uniform identity trajectory suggests a context in which the structural aspects made little room for individual agency.

Signs of growing confidence in one's assessment practice signalled the development of an academic habitus that 'fitted' into the field. The basis for the emergence of this confidence can be interpreted in different ways. There was the confidence that grew through increased engagement with the activity of assessment, along the learning-to-judge trajectory, and through establishing relationships with colleagues that provided opportunities to share experiences of the judgement process and get feedback on one's practice. But there was also the development of a different kind of confidence particularly evident in Department B (Natural Science), and to some extent in Department A (Social Science), one based on an increased sense that one understood how to 'play the game' and how to make decisions that would not require justification or would not lead to possible confrontation with one's colleagues. The development of confidence, based on either of the above interpretations, indicated the maturing of the newcomer's academic habitus and its growing harmonization with the collective habitus.

This study points to the need for academic staff development initiatives to facilitate the harmonization of the new academic habitus with the collective habitus of the communities of practice of the department, not only by helping to align the new academic habitus with the collective habitus, but also by supporting new academics in their challenging of the collective habitus and by supporting the departmental communities of practice in responding to these challenges.

The emphasis needs to be on understanding context and creating opportunities to learn within communities of practice rather than simply providing opportunities for individuals to learn in isolation. This requires a focus on supporting relationships within communities of practice that encourage the sharing of understandings and negotiations around the distributed knowledge of practice.

\section{References}

Billett, Stephen. 2001. Learning Throughout Working Life: Interdependencies at work. Studies in Continuing Education 2, no. 1: 19-35.

. 2004. Learning through work: Workplace participatory practices. In Workplace learning in Context, edited by Helen Rainbird, Alison Fuller, and Anne Munro, 10925. London: Routledge.

Bourdieu, Pierre. 1990. The Logic of Practice. Stanford, California: Stanford University Press.

- 1993. Sociology in Question. London: Sage Publications.

Bourdieu, Pierre, and Lois J Wacquant, D. 1992. An Invitation to Reflexive Sociology. The University of Chicago Press.

Brown, John Seely, Allan Collins, and Paul Duguid. 1989. Situated cognition and the culture of learning. Educational Researcher 18, no. 1: 32-42.

Eraut, Michael. 2004. Informal learning in the workplace. Studies in Continuing Education 26, no. 2: 247-73. 
Flyvbjerg, Bent. 2001. Making Social Science Matter: Why social inquiry fails and how it can begin to succeed again. Cambridge: Cambridge University Press.

Gee, James Paul. 1996. Social Linguistics and Literacies: Ideology in Discourses. London: Taylor and Francis.

Gonzalez Arnal, S, and S Burwood. 2003. Tacit Knowledge and Public Accounts. Journal of Philosophy of Education 37, no. 3: 377-91.

Jawitz, Jeff. 2007. New academics negotiating communities of practice: Learning to swim with the big fish. Teaching in Higher Education 12, no. 2: 185-97.

Lave, Jean. 1996. Teaching, as Learning, in Practice. Mind, Culture and Activity 3, no. 3: 14964.

Lave, Jean, and Etienne Wenger. 1991. Situated Learning: Legitimate peripheral participation. Cambridge: Cambridge University Press.

Lincoln, Yvonna S., and Egon G. Guba. 1985. Naturalistic Inquiry. Beverly Hills, CA: Sage Publications.

Mahar, Cheleen, Richard Harker, and Chris Wilkes. 1990. The Basic Theoretical Position. In An Introduction to the Work of Pierre Bourdieu: The Practice of Theory, edited by Richard Harker, Cheleen Mahar, and Chris Wilkes, 1-25. London: Macmillan.

Polkinghorne, Donald E. 1995. Narrative configuration in qualitative analysis. In Life History and Narrative, edited by J.A. Hatch and R. Wisniewski, 5-23. London: Falmer.

Trowler, Paul, and Peter T. Knight. 2000. Coming to Know in Higher Education: Theorising faculty entry to new work contexts. Higher Education Research and Development 19, no. 1: 27-42.

Wenger, Etienne. 1998. Communities of Practice Learning, Meaning, and Identity. Cambridge: Cambridge University Press. 